Jurnal Pemikiran \& Penelitian Psikologi

\title{
PSIKOLOGIA
}

p-ISSN: $185-0327$

e-ISSN: 2549-2136

www.jurnal.usu.ac.id/psikologia

\section{PERAN PERCEIVED VALUE DAN PROMOSI PENJUALAN TERHADAP KEPUASAN PELANGGAN DAN DAMPAKNYA TERHADAP INTENSI MEMBELI ULANG PADA PENGGUNA TRANSPORTASI ONLINE}

THE ROLE PERCEIVED VALUE AND SALES PROMOTION TOWARD CUSTOMER SATISFACTION AND IMPACT ON REPURCHASE INTENTION AMONG USERS OF ONLINE TRANSPORTION

Shoffa Malini, Zulkarnain, Eka Danta Jaya Ginting

Psikologia: Jurnal Pemikiran \& Penelitian Psikologi

Tahun 2017, Vol. 12, No. 2, hal.108-121

Artikel ini dapat diakses dan diunduh pada:

www.jurnal.usu.ac.id/psikologia

Dipublikasikan oleh:

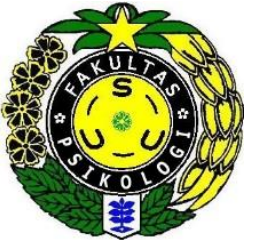

Fakultas Psikologi

Universitas Sumatera Utara

J1. Dr. Mansyur No. 7 Medan. Telp/fax: 061-8220122

Email: psikologia@usu.ac.id 


\title{
PERAN PERCEIVED VALUE DAN PROMOSI PENJUALAN TERHADAP KEPUASAN PELANGGAN DAN DAMPAKNYA TERHADAP INTENSI MEMBELI ULANG PADA PENGGUNA TRANSPORTASI ONLINE
}

\author{
Shoffa Malini, Zulkarnain, Eka Danta Jaya Ginting \\ Universitas Sumatera Utara
}

\begin{abstract}
ABSTRAK
Penelitian ini dilakukan untuk mengetahui peran perceived value dan promosi penjualan terhadap kepuasan pelanggan, serta pengaruh kepuasan pelanggan terhadap intensi membeli ulang pada pengguna transportasi online. Pendekatan penelitian ini adalah kuantitatif dengan menggunakan teknik purposive sampling yang melibatkan 355 orang pengguna transportasi online. Teknik analisis data yang digunakan adalah Analisis jalur. Hasil analisis statistik menunjukkan bahwa perceived value dan promosi penjualan berpengaruh signifikan dan positif terhadap kepuasan pelanggan. Kemudian kepuasan pelanggan berpengaruh signifikan dan positif terhadap intensi membeli ulang. Selain itu, perceived value dan promosi penjualan berpengaruh signifikan dan positif terhadap intensi membeli ulang melalui mediasi kepuasan pelanggan. Implikasi dari penelitian ini dapat membantu pihak transportasi online untuk mempertahankan dan terus meningkatkan kualitas nilai jasa yang ditawarkan bagi penggunanya, baik dari segi manfaat promosi penjualan yang ditawarkan, maupun penciptaan custumer perceived value yang positif yang akan berdampak baik kepada peningkatan kepuasan pelanggan dan intensi untuk menggunakannya kembali.
\end{abstract}

Kata-kata kunci: Intensi Membeli Ulang, Kepuasan Pelanggan, Perceived Value, Promosi Penjualan, dan Transportasi online

\section{THE ROLE PERCEIVED VALUE AND SALES PROMOTION TOWARD CUSTOMER SATISFACTION AND IMPACT ON REPURCHASE INTENTION AMONG USERS OF ONLINE TRANSPORTION}

\begin{abstract}
S
This research was conducted to find out the role of perceived value and sales promotion to customer satisfaction, and the influence of customer satisfaction to repurchase intention on the user of online transportation. This research is quantitative by using purposive sampling technique involving 355 usersof online transportation. Data analysis technique isused path analysis. The statistical analysis result showed that perceived value and sales promotion significant and positivelyinfluenced to customer satisfaction. Then customer satisfaction significant and positively impact on repurchase intention. In addition, perceived value and sales promotion significant and positively impact on repurchase intention through customer satisfaction. The implications of this research can help the transporter's to maintain and continuously improve the quality of services offered to their users, both in terms of the benefits of sales promotion offered, as well as the creation of a positive customer perceived value that will impact both the increased customer satisfaction and the intention to use it back.
\end{abstract}

Keywords: Repurchase Intention, Customer Satisfaction, Perceived Value, Sales Promotion, and Online Transportation.

*Korespondensi mengenai penelitian ini dapat dilayangkan kepada: Psikologia@usu.ac.id
Rekomendasi mensitasi:

Malini,S. Zulkarnain, \& Ginting,E.D.J. (2017). Peran Perceived Value dan Promosi Penjualan terhadap Kepuasan Pelanggan dan Dampaknya terhadap Intensi Membeli Ulang pada Pengguna Transportasi Online. Psikologia :Jurnal Pemikiran dan Penelitian Psikologi, 12(2), 108-121. 
Beberapa tahun belakangan ini di Indonesia bisnis transportasi berbasis aplikasi online saat ini memang tengah diminati masyarakat. Dimana aplikasi transportasi berbasis online ini dimaksudkan untuk memudahkan para penggunanya dalam mengakses media transportasi yang di gunakan dalam mobilitas sehari-hari (Yunanto, 2016).

Berdasarkan sebuah jajak pendapat yang dilakukan YouGov (2015) sepanjang 7-13 Agustus 2015 terhadap 4.785 panelis seluruh Indonesia pengguna transportasi online. Secara umum $82 \%$ responden setuju dengan kehadiran transportasi online. Hal yang menarik adalah di kotakota yang belum memiliki layanan transportasi online ini berharap layanan ojek onlineini segera hadir di kota mereka. Dengan adanya survei yang dilakukan YouGov tersebut membuat pengguna transportasi online merasa kebutuhannya telah terpenuhi dan puas akan manfaat jasa yang ditawarkan transportasi berbasis aplikasi online.

Menurut Mowen \& Minor (2002), menjelaskan setelah konsumen menerima dan merasakan manfaat ataupun nilai dari suatu produk, konsumen tersebut sudah memiliki rasa puas dan komitmen terhadap produk atau jasa tersebut, dimana pada akhirnya dapat menimbulkan tujuan untuk membeli ulang produk itu dimasa yang akan datang karena adanya pemenuhan kebutuhan suatu barang atau jasa. Apabila customer merasa keinginan serta kebutuhannya terpenuhi oleh suatu barang dan jasa yang di tawarkan oleh suatu perusahaan, maka hal tersebut dapat meningkatkan intensi membeli ulang (Christiani, 2012).

Hellier, Philip, Geursen, Carr dan Rickard (2003) menyatakan bahwa intensi membeli ulang merupakan keputusan konsumen tentang membeli lagi sebuah jasa perusahaan yang sama dengan memperhitungkan situasi dan kondisi tingkat kepuasaan.Oleh Karena itu, intensi membeli ulang suatu produk atau jasa akan muncul ketika pelangganmerasa bahwa pengalaman terhadap suatu produk atau jasa yang pelanggan terima bisa memberikan kepuasan terhadap diri pelanggan tersebut (Firmawan \& Shaleh, 2013).

Kepuasan pelanggan menurut Tjiptono (2008) didefinisikan sebagai evaluasi yang memberikan hasil dimana pengalaman yang dirasakan setidaknya sama baiknya atau sesuai dengan yang diharapkan.Kepuasaan pelanggan dipengaruhi oleh beberapa faktor penentu keberhasilan suatu program pemasaran agar menarik konsumen untuk melakukan pembelian ulang atas suatu produk atau jasa seperti kualitas pelayanan, harga, promosi, brand image, customer perceived value (Roza, 2011; Syamsiah, 2009). Perceived value ini menjadi salah satu faktor yang sering mempengaruhi pada kepuasan pelanggan (Anggreini, 2015; Syamsiah, 2009).Perceived value dapat dinyatakan sebagai pertukaran antara manfaat yang dirasakan (perceived benefits) dan biaya yang dirasakan (perceived costs) (jen \& Hu,2003). Sesuai atau tidaknya suatu penawaran dengan harapan akan mempengaruhi kepuasan pelanggan dan besar kemungkinan pelanggan akan melakukan pembelian ulang (repurchase) (Firmawan \& Saleh, 2013).

$\begin{array}{llr}\text { Selain } & \text { itu, faktor yang } \\ \text { mempengaruhi } & \text { kepuasan pelanggan } \\ \text { terhadap suatu } & \text { produk atau } & \text { jasa yang } \\ \text { ditawarkan } & \text { perusahaan, } & \text { tentunya }\end{array}$


perusahaan perlu melakukan strategi promosi penjualan (Roza, 2011; Krisna, 2010). Dimana strategi promosi penjualan ini harus dikemas secara apik dan menarik sebagai alat untuk mendorong penjualan dan memperoleh respon pasar yang lebih cepat (Swasta,1999).Grewal dan Levy (2008) menjelaskan bahwa promosi penjualan sebagai insentif spesial atau program-program menarik yang mendorong konsumen untuk melakukan pembelian produk dan jasa dan dalam waktu tertentu.Promosi penjualan yang berkembang pada suatu produk atau jasa dapat berakibat pada meningkatnya kepuasan pelanggan (Krisna, 2010). Menurut Yamit (2005) kepuasan yang dialami konsumen mendorong konsumen untuk melakukan intensi pembelian ulang (intensi membeli ulang) atas produk dan jasa di masa yang akan datang.

Beberapa penelitian menyatakan
bahwa hasil kepuasan pelanggan mempunyai dampak positif bagi customer intensi membeli ulang (Adhisti\& Tri, 2016; Muzahid \&Noorjahan, 2009; Solvang, 2007). Dimana Penambahan nilai atribut merupakan hal penting bagi pelanggan ketika ia memilih berbagai produk atau jasa yang ditawarkan perusahaan, dan kemungkinan untuk membeli kembali pasti lebih besar jika perusahaan berhasil memberikan sesuatu kepuasan bagi pelanggannya melalui adanya value dan promosi penjualan yang diberikan kepada pelanggan (Ravald \& Gronroos, 1996; Cristiani, 2012; Triastuti \& Tae 2012; Krisna, 2010; Syamsiah, 2009). Dimana dalam penelitian Syamsiah (2009) menemukan bahwa perceived value memiliki efek positif pada kepuasan pelanggan. Penelitian ini berhasil membuktikan bahwa semakin tinggi nilai yang dirasakan pelanggan, maka akan semakin tinggi kepuasan pelanggan. Selain itu hasil penelitian Koyong, Tumbel, dan Sepang (2016) menunjukan bahwa promosi penjualan berpengaruh terhadap kepuasan konsumen. Dimana variabel promosi penjualan dapat di jadikan startegi perusahaan untuk mendapatkan perhatian konsumen, dan menadapatkan kepuasan konsumen. Kepuasan pelanggan ini pada gilirannya akan mendorong konsumen untuk intensi membeli ulang. Oleh karena itu, dalam penelitiannya Hellier et al (2003) menyatakan bahwa kepuasan pelanggan mempunyai pengaruh positif secara langsung pada intensi membeli ulang.

Berdasarkan uraian tersebut, terlihat bahwa terdapat pengaruh positif dari perceived value dan promosi penjualan terhadap intensi membeli ulang melalui mediasi kepuasan pelanggan. Artinya semakin positif nilai yang dirasakan konsumen (Perceived value) dan semakin bermanfaat promosi penjualan terhadap suatu produk atau jasa, maka akan tinggi pula kepuasan pelanggan, dan semakin tinggi pula dampaknya terhadap intensi membeli ulang. Oleh Karena itu, penelitian ini dilakukan untuk mengetahui bagaimana peran perceived value dan promosi penjualan terhadap kepuasan pelanggan, serta bagaimana pengaruh kepuasan pelanggan terhadap intensi membeli ulang pada pengguna transportasi online.

\section{Kerangka Teoritis}

\section{Intensi Membeli Ulang}

Intensi membeli ulang mengacu pada kemungkinan dalam menggunakan penyedia layanan kembali dimasa depan (Mosavi\&Ghaedi, 2011). Lebih lanjut 
Hellier et al (2003) mendefinisikan intensi membeli ulang sebagai penilaian individu mengenai pembelian kembali layanan yang disediakan perusahaan yang sama, dengan mempertimbangkan situasi saat ini dan kemungkinan situasi dimasa mendatang. Intensi membeli ulang ini terdiri dari tiga indicator yaitu selalu menjadi pilihan utama bagi konsumen untuk menikmati suatu barang atau jasa, bersedia untuk melakukan kembali transaksi atau pembelian suatu barang atau jasa di perusahaan yang sama, dan keinginan untuk menggunakan kembali dengan mengajak serta teman-teman yang lain. (Triastuti \& Tae, 2012).

\section{Kepuasan Pelanggan}

Kepuasan pelanggan menurut Tjiptono (2008) didefinisikan sebagai evaluasi yang memberikan hasil dimana pengalaman yang dirasakan setidaknya sama baiknya atau sesuai dengan yang diharapkan. Sedangkan Supranto (2006) juga menjelaskan bahwa kepuasan pelanggan adalah kinerja suatu barang sekurang-kurangnya sama dengan apa yang diharapkan. Indikator yang digunakan untuk mengukur variabel kepuasan pelanggan adalah adanya Rasa senang yang menunjukkan sejauh mana para pelanggan tersebut merasa senang dengan pengalaman selama berhubungan dengan pihak perusahaan, kepuasan terhadap pelayanan yang menunjukkan sejauh mana para pelanggan merasa puas dengan cara dan sikap para petugas dalam melayani, serta memperhatikan pelayanan yang sesuai diharapkan pelanggan dan kepuasan terhadap sistem yang menunjukkan sejauh mana kecepatan dan kemudahan sistem pelayanan yang disediakan perusahaan mampu memberikan

kepuasan

kepada pelanggannya.

\section{Perceived Value}

Hellier at al (2003) menjelaskan bahwa Perceived value merupakan penilaian pelanggan secara keseluruhan dari layanan, penilaian pelanggan tentang apa yang diterima (manfaat yang diberikan oleh layanan), dan apa yang diberikan (biaya atau pengorbanan dalam memperoleh dan memanfaatkan layanan).Lebih lanjut lagi, Kotler dan Keller (2007) menyatakan bahwa nilai yang dipersepsikan pelanggan (customer perceived value) merupakan selisih antara penilaian pelanggan prospektif atas semua manfaat dan biaya dari suatu penawaran terhadap alternatifnya. Pengukuran perceived value ini dengan menggunakan skala dariSweeney dan Soutar (2001) yang disebut sebagai PERVAL (perceived value), yang digunakan untuk menilai persepsi konsumen terhadap nilai suatu produk atau jasa. Adapun dimensi dari PERVAL yaitu:Functional value (quality/performance value), Functional value (price of money), Emotional Value, danSocial Value.

\section{Promosi Penjualan}

Grewal dan Levy menjelaskan bahwa promosi penjualan sebagai insentif spesial atau programprogram menarik yang mendorong konsumen untuk melakukan pembelian produk dan jasa dan dalam waktu tertentu.Selain itu Kotler dan Keller (2007) mengemukakan bahwa promosi penjualan adalah sebagai kumpulan alat-alat insentif yang sebagian besar jangka pendek, yang dirancang untuk merangsang pembelian produk atau jasa tertentu yang ditawarkan dengan lebih cepat dan lebih besar oleh 
konsumen. Promosi penjualan di ukur berdasarkan penelitian Chandon, Wansink, dan Laurent (2000) yaituadanya keuntungan atau manfaatdari kegiatan promosi penjualan. Promosi penjualan dapat memberikan nilai pelanggan yang lebih tinggi dengan manfaat yang diperoleh. Manfaat atau keuntungan yang di peroleh oleh konsumen dari promosi penjualan yaitu Savings (Penghematan Biaya), Quality (Peningkatan Kualitas Dari Produk Atau Jasa Yang Dibeli), Convenience (Mengurangi Pencarian Dan Pengambilan Biaya), Value- expression (Ekspresi dan Peningkatan self-concept dan personal values), Exploration (Stimulation and variety), danEntertainment (Hiburan dan Nilai Estetika).

Kerangka pemikiran yang mendasari penelitian ini di tunjukkan pada Gambar 1 sebagai berikut: populasi dalam penelitian ini adalah pernah menggunakan jasa layanan transportasi online sebanyak 1 sampai 2 kali. Metode pengambilan sampel penelitian ini menggunakan teknik purposive sampling yaitu teknik pengambilan sampel nonprobabilitas yang sampelnya dipilih berdasarkan pada karakteristik tertentu dianggap mempunyai sangkutpaut dengan karakteristik populasi yang sudah diketahui sebelumnya (Umar, 2008).

\section{Alat ukur}

Alat ukur pengumpulan data yang akan digunakan dalam penelitian ini adalah alat ukur self report dan skala sebagai alat ukur. Skala adalah suatu prosedur pengambilan data yang merupakan suatu alat ukur aspek afektif yang merupakan konstruk atau konsep psikologis yang menggambarkan aspek kepribadian individu (Azwar, 2012).

\section{Gambar 1. Dinamika Hubungan Antar Variabel}

Perceived Value skala PERVAL dar Sweeney dan Soutar (2001):

Functional value (quality/performance value,

Functional value (price of money)

Emotional Value

4. Social Value

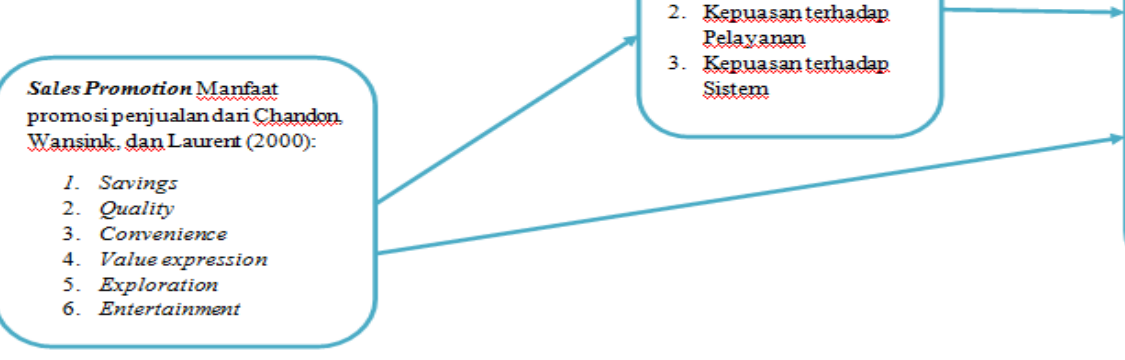

HASIL

\section{METODE}

\section{Partisipan}

Subjek penelitian pada penelitian ini adalah sebanyak 355 orang pengguna transportasi online. Dengan karakteristik

\section{Hasil Uji Normalitas}

Uji normalitas sebaran dilakukan dengan menggunakan one sample kolmogorov smirnov test yang dilakukan 
pada variabel intensi membeli ulang, kepuasan pelanggan, perceived value, dan promosi penjualan. Analisis data kolmogorov smirnov menunjukkan bahwa variabel intensi membeli ulang menunjukkan sebaran normal dengan nilai signifikansi $(\mathrm{P})=0,60>0,05$. Pada variabel kepuasan pelanggan menunjukkan sebaran normal dengan nilai signifikansi $(\mathrm{P})=1,08$ > 0,05. Pada variabel perceived value juga menunjukkan sebaran normal dengan nilai $\mathrm{P}=0,69>0,05$. Sedangkan pada variabel promosi penjualan menunjukkan sebaran normal dengan nilai signifikansi $(\mathrm{P})=$ $1,91>0,05$.

\section{Hasil Uji Linearitas}

Analisis data ini menghasilkan variabel kepuasan pelanggan dengan perceived value memilliki taraf signifikansi $\mathrm{P}=0,000$. Sedangkan untuk variabel kepuasan pelanggan dengan promosi penjualan memiliki taraf signifikansi $\mathrm{P}=0,000$. Pada variabel intensi membeli ulang dengan kepuasan pelanggan memiliki taraf signifikansi $\quad P$ $=0,000$. Pada variabel intensi membeli ulang dengan perceived value memiliki taraf signifikansi $\mathrm{P}=0,000$. Pada variabel intensi membeli ulang dengan promosi penjualaan memiliki taraf signifikansi $\mathrm{P}=$ 0,000. Hasil tersebut menunjukkan bahwa taraf signifikansi $0,000<0,05$ maka hubungannya antara variabel bebas dengan variabel tergantung dinyatakan linier.

\section{Hasil UJi Autokorelasi}

Berdasarkan nilai statistik dari uji Durbin-Watson di atas lebih besar dari 1 dan lebih kecil dari 3 yaitu 1.795 dan 1,729.Maka disimpulkan tidak terjadi autokorelasi.

\section{Hasil Uji Multikorlinearitas}

Metode pengujian yang digunakan adalah uji VIF (Variance Inflation Factor). Berdasarkan tabel di atas diketahui bahwa tidak terdapat nilai variance inflaction factor (VIF) masing-masing variabel bebas sebesar 1,645, 1,682, 1,971 dan 1,759. Dengan nilai Tolerance masing-masing $0,608,0,595,0,507$, dan 0,568. Karena nilai VIF $<5$ dan nilai tolerance $>0.1$, dapat disimpulkan bahwa tidak terjadi multikolinearitas antar variabel bebas. Dengan demikian, diasumsikan bahwa tidak terjadi hubungan linear antar variabel bebas.

\section{Hasil UJi Heterokedesitas}

Berdasarkan dari grafik di dapat dilihat bahwa sebaran titik dalam grafik menyebar secara acak (no systematic pattern) disekitar 0, dan titik-titik menyebar di atas dan di bawah angka 0 pada sumbu Y. Maka disimpulkan bahwa tidak terjadi gejala heterokedesitas dalam model regresi. Hal tersebut dapat dilihat pada grafik berikut:

Gambar 2. Grafik perceived value dan promosi penjualan terhadap kepuasan pelanggan

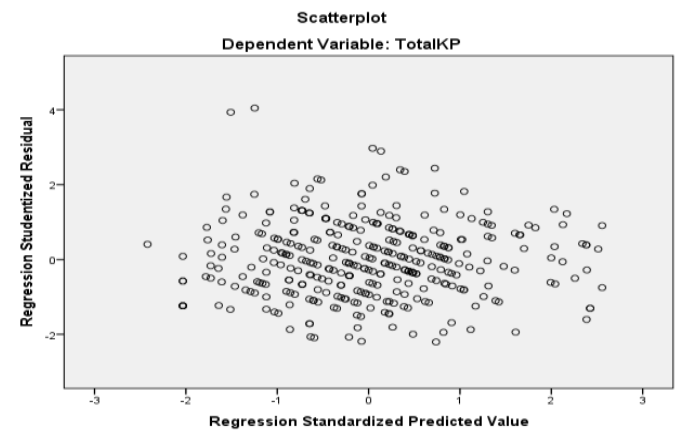


Gambar 3. Grafik perceived value, promosi penjualan dan kepuasan pelanggan terhadap intensi membeli ulang.

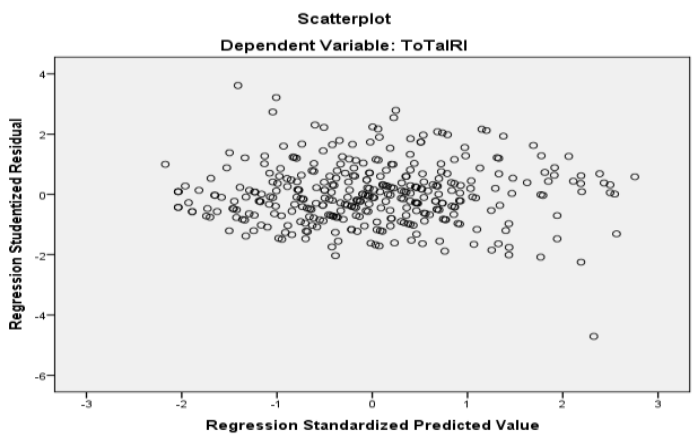

\section{Hasil Uji Hipotesa Penelitian}

Teknik analisis data yang digunakan dalam menganalisis data penelitian ini adalah Analisis jalur (Path Analysis) yang merupakan pengembangan statistik regresi, sehingga analisis regresi dapat dikatakan sebagai bentuk khusus analisis jalur. Adapun hasil analisa hipotesa penelitian ini adalah:

Tabel. 1

\section{Hasil Analisis Koefisien Regresi Parsial}

Berdasarkan tabel 1 tersebut, dihasilkan F sebesar 202,215 dengan tingkat signifikansi $5 \%$ atau 0,05 dengan hasil $0.000<0.05$, menyatakan bahwa perceived value berpengaruh sangat signifikan terhadap kepuasan pelanggan. Dengan koefisien determinan (adjusted $\mathrm{R}$ square) yakitu sebesar 0.362 atau $36,2 \%$, artinya sumbangan variabel perceived value terhadap kepuasan pelanggan adalah $36,2 \%$. Dengan demikian hipotesa pertama penelitian ini diterima.

Berdasarkan tabel 1, dihasilkan $\mathrm{F}$ sebesar 142,548 dengan tingkat signifikansi 5\% atau 0,05 dengan hasil $0.000<0.05$. Maka dapat disimpulkan bahwa promosi penjualanberpengaruh sangat signifikan terhadap kepuasan pelanggan. Dengan nilai koefisien determinan (adjusted $\mathrm{R}$ square) yakitu sebesar 0.286 atau 28,6\%, artinya sumbangan variabel promosi penjualan

\begin{tabular}{|c|c|c|c|c|c|c|}
\hline $\begin{array}{c}\text { Variabel } \\
\text { Dependent }\end{array}$ & $\begin{array}{c}\text { Variabel } \\
\text { Independent }\end{array}$ & $\mathbf{F}$ & Sig. & Beta & $\mathbf{R}$ & $\begin{array}{l}\text { Ajusted R } \\
\text { Square }\end{array}$ \\
\hline \multicolumn{7}{|l|}{ Blok 1} \\
\hline \multirow{4}{*}{$\begin{array}{l}\text { Kepuasan } \\
\text { Pelanggan }\end{array}$} & Perceived Value & 202,215 & 0,000 & 0,603 & 0,603 & 0,362 \\
\hline & Promosi Penjualan & 142,548 & 0,000 & 0,536 & 0,536 & 0,286 \\
\hline & PV dan PP & 120,043 & 0,000 & $0,440(\mathrm{PV})$ & 0,637 & 0,402 \\
\hline & & & & $0,261(\mathrm{PP})$ & & \\
\hline \multicolumn{7}{|l|}{ Blok 2} \\
\hline \multirow{10}{*}{$\begin{array}{l}\text { Intensi } \\
\text { Membeli } \\
\text { Ulang }\end{array}$} & Perceived Value & 167,78 & 0,000 & 0,568 & 0,568 & 0,320 \\
\hline & Promosi Penjualan & 255,225 & 0,000 & 0,648 & 0,648 & 0,418 \\
\hline & Kepuasan Pelanggan & 145,004 & 0,000 & 0,540 & 0,540 & 0,289 \\
\hline & PV dan KP & 109,368 & 0,000 & $0,310(\mathrm{KP})$ & 0,619 & 0,380 \\
\hline & & & & $0,381(\mathrm{PV})$ & & \\
\hline & PP dan KP & 156,996 & 0,000 & $0,270(\mathrm{KP})$ & 0,687 & 0,468 \\
\hline & & & & $0,503(\mathrm{PP})$ & & \\
\hline & $\mathrm{PV}, \mathrm{PP}$ dan KP & 111,223 & 0,000 & $0,203(\mathrm{KP})$ & 0,698 & 0,487 \\
\hline & & & & $0,177(\mathrm{PV})$ & & \\
\hline & & & & $0,428(\mathrm{PP})$ & & \\
\hline
\end{tabular}


terhadap kepuasan pelanggan adalah $28,6 \%$. Dengan demikian, hipotesis kedua pada penelitian ini diterima.

Dengan dihasilkan nilai $\mathrm{F}$ sebesar 145,004 dengan tingkat signifikansi 5\% atau 0,05 dengan hasil $0.000<0.05$. Maka dapat disimpulkan bahwa kepuasan pelangganberpengaruh sangat signifikan terhadap intensi membeli ulang. Dengan nilai koefisien determinan (adjusted $\mathrm{R}$ square) yakitu sebesar 0.289 atau 28,9\%, artinya sumbangan variabel kepuasan pelanggan terhadap intensi membeli ulang adalah 28,9\%. Dengan demikian, hipotesis ketiga pada penelitian ini diterima.

Berdasarkan hasil analisa path analisis dua jalur diatas, dengan hasil signifikansi $0,000<0,05$. Maka hipotesa keempat penelitian ini diterima yaitu Ada pengaruh perceived value terhadap intensi membeli ulang melalui mediasi kepuasan pelanggan. Dengan pencarian pengaruh langsung (direct effect) perceived value terhadap intensi membeli ulang sebesar 0.320 atau $32 \%$, sedangkan nilai pengaruh tidak langsung yaitu $\mathrm{IE}=0,603 \times 0,540=$ 0,325 atau $32,5 \%$ dan Pengaruh Total yaitu $0,177+0,325=0,502$ atau $50,2 \%$.

Berdasarkan hasil analisa path analisis dua jalur diatas, dengan hasil signifikansi $0,000<0,05$. maka hipotesa kelima penelitian ini diterima yaitu ada pengaruh promosi penjualan terhadap intensi membeli ulang melalui mediasi kepuasan pelanggan. Pencarian pengaruh langsung (direct effect) promosi Penjualanterhadap intensi membeli ulang sebesar 0,418 atau $41,8 \%$, sedangkan sedangkan nilai pengaruh tidak langsung yaitu IE $=0,536$ x $0,540=0,289$ atau $28,9 \%$ dan Pengaruh Total : $0,428+0,289=0,717$ atau $71,7 \%$.

\section{DISKUSI}

\section{Pengaruh Perceived Value terhadap Kepuasan Pelanggan}

Hasil penelitian ini menunjukkan bahwa perceived value berpengaruh secara positif dan sangat signifikan terhadap kepuasan pelanggan. Hal ini berati semakin positif nilai yang dirasakan oleh pengguna maka semakin tinggi pula kepuasaan pengguna transportasi online. Kepuasan ini merupakan evaluasi menyeluruh terhadap kesenjangan antara apa yang diharapkan pelanggan dengan kinerja perusahaan dalam memberikan pelayanan (Syamsiah, 2009).

Penelitian ini sesuai dengan hasil penelitian Khraim, Al-Jabaly dan Khraim (2014) menemukan bahwa perceived value yang dirasakan pelanggan berpengaruh terhadap kepuasan pelanggan. Selain itu, hasil penelitian Subagio dan Saputra (2012) menunjukkan bahwa perceived value berpengaruh terhadap kepuasan pelanggan. Hasil ini menunjukkan bahwa responden menilai sejauh mana perceived value ikut menentukan sejauh mana tingkat kepuasan konsumen. Perceived value yang meningkat akan menghasilkan konsumen yang puas. Perceived value yang positif diperoleh adanya hubungan konsumen dengan perusahaan yang memadai dari kinerja perusahaan dan menjadi rendah ketika konsumen mendapatkan hasil negatif tentang perceived value dari kinerja perusahaan(Umar, 2003). Hal ini membuktikan bahwa perceived value merupakan elemen yang penting dalam pembentukan kepuasan pelanggan khususnya dalam usaha jasa, seperti jasa transportasi online. 


\section{Pengaruh Promosi Penjualan terhadap Kepuasan Pelanggan}

Dari hasil penelitian ini, ditemukan bahwa promosi penjualan berpengaruh positif dan sangat signifikan terhadap kepuasan pelanggan.Hal ini berati bahwasemakin menarik atau bermanfaat suatu promosi penjualan yang diperoleh pengguna transportasi online, maka semakin tinggi pula tingkat kepuasan pelanggan. begitu juga sebaliknya semakin kurang menarik atau tidak bermanfaat promosi penjualan bagi pengguna, maka semakin rendah pula tingkat kepuasan. Hal ini sesuai yang dikatakan Lupiyoadi dan Hamdani (2013) menjelaskan bahwa tujuan promosi sebagai alat komunikasi antara perusahaan dan konsumen, serta sebagai alat untuk mempengaruhi konsumen dalam kegitan pembelian atau penggunaan jasa sesuai dengan keinginan dan kebutuhannya. Oleh Karena itu apabila kebijakan promosi dapat menarik dan mempengaruhi pelanggan dengan berbagai macam alat promosi penjualan sesuai yang diharapkan, maka akan berdampak pada kepuasaan pelanggan (Triandinny, 2015).

Hasil penelitian Khan et.al (2012) membuktikan bahwa hasil promosi produk atau jasa dapat membantu dengan cara terbaik untuk membangun hubungan dengan pelanggan, karena semua orang mencari kesepakatan terbaik yang mempunyai kesesuaian. Hal ini terjadi ketika informasi penawaran yang diberikan pihak transportasi online seperti adanya promo diskon dan penawaran khusus yang dapat membangun hubungan baik dengan pengguna transportasi online dalam rangka meningkatkan kepuasan pelanggan.

\section{Pengaruh Kepuasan Pelanggan terhadap Intensi Membeli Ulang}

Hasil penelitian ini menemukan bahwa ada pengaruh positif dan sangat signifikan kepuasan pelanggan terhadap intensi membeli ulang. Hal ini menunjukkan bahwa pengguna yang merasa puas atas jasa transportasi online, maka akan timbul intensi untuk menggunakan kembali. Begitu juga sebaliknya bagi pengguna yang kurang puas dengan jasa transportasi online cenderung tidak berkeinginan dan tidak memiliki intensi untuk menggunakan jasa transportasi online kembali.

Kepuasan pelanggan menjadi hal penting bagi perusahaan karena memiliki dampak positif pada intensi membeli kembali pelanggan di masa depan (Cronin, Brady \& Hult, 2000). Hellier, et al (2003) menyatakan bahwa kepuasan pelanggan secara keseluruhan berhubungan kuat tehadap intensi konsumen untuk menggunakan kembali dari penyedia produk atau jasa yang sama. Hasil penelitian ini sesuai dengan hasil penelitian Ibzan, Balarabe, dan Jakada (2016) yang menyatakan bahwa kepuasan pelanggan berpengaruh positif terhadap intensi membeli ulang. Pengaruh yang signifikan antara kepuasan pelanggan dengan intensi membeli ulang tersebut memberikan pemahaman bahwa untuk meningkatkan intensi membeli ulang pengguna, maka perlu memperhatikan dan meningkatkan kepuasan pengguna akan rasa senang selama menggunakan, pelayanan driver, serta sistem dari transportasi online. 
Pengaruh perceived Value Terhadap Intensi Membeli Ulang Melalui Mediasi Kepuasan Pelanggan

Hasil penelitian ini menemukan bahwa perceived value ini juga memiliki pengaruh tidak langsung terhadap intensi membeli ulang melalui mediasi kepuasan pelanggan. Penelitian ini menunjukkan bahwa perceived value yang dirasakan pengguna mampu memberikan kepuasan pelanggan serta memberikan dampak terhadap intensi membeli ulang pengguna transportasi online.

Customer perceived value positif ini akan muncul ketika kinerja dari suatu produk atau jasa memenuhi harapan konsumen. Ketika konsumen merasa harapannya telah terpenuhi maka akan timbul rasa puas pada konsumen. Kemudian rasa puas tersebut akan berdampak positif secara langsung terhadap intensi membeli ulang (Tunjungsari dan Lunardy, 2016). Begitu juga sebaliknya, ketika nilai yang di persepsikan konsumen tidak sesuai harapan, maka kekecewaan dan rasa ketidakpuasan yang muncul (Umar, 2003). Ketidakpuasan konsumen ini akan berdampak pada ketidakinginan untuk menggunakan produkatau jasa kembali (Yulisetiarini, Subagio, Paramu \& Irawan, 2017).

Hasil penelitian ini juga membuktikan bahwa pengaruh perceived value secara tidak langsung lebih tinggi daripada secara langsung. Hal ini dikarenakan pembelian ulang yang dilakukan pengguna dipengaruhi adanya kepuasan yang diperoleh dari nilai yang dipersepsikan pengguna selama menggunakan transportasi online. Apabila pelanggan merasa puas dengan yang didapatkannya maka pelanggan akan menimbulkan intensi membeli ulang. Hasil penelitian ini sejalan dengan hasil penelitian Kurniawan dan Kuncoro (2014) menyatakan bahwa adanya hubungan dan pengaruh yang signifikan antaraPerceived Value dengan intensi membeli ulang melalui adanya kepuasan pelanggan.

\section{Pengaruh Promosi Penjualan Terhadap Intensi Membeli Ulang Melalui Mediasi Kepuasan Pelanggan}

Hasil penelitian ini menemukan bahwa promosi penjualan ini juga memiliki pengaruh tidak langsung terhadap intensi membeli ulang melalui mediasi kepuasan pelanggan. Hasil penelitian ini sesuai yang dikatakan Semuel (2006) bahwa kepuasan pelanggan dapat menjadi variabel penghubung antara aplikasi bauran pemasaran yang terdiri dari personal selling, iklan, publisitas dan promosi penjualan terhadap intensi membeli ulang.

Koyong, Tumbel, dan Sepang(2016) menjelaskan bahwa promosi penjualan dapat di jadikan startegi perusahaan untuk mendapatkan perhatian konsumen melalui berbagai macam alat promosi penjualan seperti diskon, voucher dan penawaran lainnya, yang nantinya dapat mempengaruhi kepuasan pelanggan. Selain itu, Yamit (2005) menjelaskan bahwa kepuasan yang dialami konsumen mendorong konsumen untuk melakukan pembelian ulang atas produk dan jasa di masa yang akan datang.

Sementara itu, pengaruh tidak langsung promosi penjualan terhadap intensi membeli ulang melalui kepuasan pelanggan memiliki nilai yang lebih 
rendah dari pengaruh secara langsung. Hal ini bermakna bahwa pengaruh mediasi kepuasan pelanggan berlaku bagi promosi penjualan terhadap intensi membeli ulang, namun kontribusi yang diberikan tidaklah sebesar kontribusi yang diberikan secara langsung. Hal ini dikarenakan promosi penjualan yang diberikan pihak transportasi online lebih menarik pengguna untuk melakukan transaksi kembali, meskipun kontribusi kepuasan pelanggan tidak memiliki pengaruh yang begitu besar.

\section{KESIMPULAN}

Berdasarkan hasil yang diperoleh dalam penelitian ini, membuktikan bahwa Perceived value berpengaruh secara positif dan sangat signifikan terhadap kepuasan pelanggan. Hal ini berati semakin positif nilai kegunaan dari suatu jasa berdasarkan hasil persepsi dari manfaat yang diterima oleh pengguna maka semakin tinggi pula kepuasaan pengguna Transportasi online. Selain itu, promosi penjualan juga memiliki pengaruh positif dan sangat signifikan terhadap kepuasan pelanggan. Hal ini berati bahwa semakin menarik atau bermanfaat suatu promosi penjualan yang diperoleh pengguna transportasi online, maka semakin tinggi pula tingkat kepuasan pelanggan. Dan pada akhirnya, kepuasan pelanggan berpengaruh positif dan sangat signifikan terhadap intensi membeli ulang. Hal ini berati bahwa semakin tinggi kepuasan pengguna transportasi online, maka semakin tinggi pula tingkat intensi membeli ulang pengguna Transportasi online.

Penelitian ini juga membuktikan bahwa ada pengaruh perceived value dan promosi penjualanterhadap intensi membeli ulang melalui mediasi kepuasan pelanggan. Dimana pengaruh secara tidak langsung pada perceived value lebih besar daripada pengaruh secara langsung terhadap intensi ulang. Sedangkan pengaruh secara langsung promosi penjualan lebih besar daripada pengaruh secara tidak langsung terhadap intensi membeli ulang.

\section{SARAN}

Berdasarkan hasil penelitian, ditemukan bahwa sebagian besar alasan pengguna menggunakan transportasi online ialah karena harga yang terjangkau dan praktis. Oleh karena itu, disarankan untuk penelitian lanjutan agar menguji pengaruh dari variabel harga dan kemudahan menggunakan transportasi online yang mungkin memiliki kontribusi terhadap intensi membeli ulang atau kepuasan pelanggan.

Selain itu, sebaiknya pihak Transportasi online mempertahankan dan terus meningkatkan kualitas nilai jasa yang ditawarkan bagi penggunanya, baik dari segi manfaat promosi penjualan yang ditawarkan, maupun penciptaan custumer perceived value yang positif. Karena dengan memberikan perceived value yang positif dan promosi penjualan yang bermanfaat akan berdampak baik kepada peningkatan kepuasan pelanggan dan intensi untuk menggunakannya kembali.

\section{REFERENSI}

Adhisti, P.D., \& Tri,A.S.R. (2016). Analisis pengaruh faktor-faktor minat beli ulang dengan kepuasan pelanggan sebagai variabel intervening (studi kasus pada pelanggan Hest'in modiste di 
Jakarta). Diponegoro Journal of Management, 5(2), 1-9.

Anggreni, P. (2015). Pengaruh perceived value terhadap kepuasan dan minat beli ulang pelanggan pasar umum Ubud. Jurnal Telaah Bisnis, 16(2), 101-118.

Azwar, S. (2012). Penyusunan skala psikologi. Yogyakarta : Pustaka Pelajar.

Christiani, D. S. (2012).Pengaruh perceived value terhadap repurchase intention (studi pada Sushi Tei Plaza Indonesia). (Skripsi). Universitas Indonesia.Depok.

Chandon, P., Wansink, B., \& Laurent, G. (2000). A Benefit congruency framework of sales promotion effectiveness. Journal of Academy Of Marketing Science, 64, 65-81.

Cronin, J. J., Brady, K. M., \& Hult, G. T. (2000). Assesing the effects of quality, value, and customer satisfaction on consumer behavioral intentions in service environments. Journal of Retailing, 76(3), 193-218.

Firmawan, A.R., \& Saleh, L. (2013). Pengaruh kualitas layanan dan nilai yang dirasakan terhadap niat pembelian ulang melalui mediasi kepuasan pelanggan restoran solaria di Surabaya. Journal of Business and Banking, 3(2), 151 -164.

Grewal \& Levy. (2008). Marketing. New York : Mc-Graw Hill

Hellier., Philip, K., Geursen, G. M., Carr, R., \& Rickard, J. A. (2003). Customer repurchase intention: a general structural equation model. European Journal of Marketing, 37(11/12), 1762-1800.
Ibzan, E., Balarabe, F., \& Jakada, B. (2016). Consumer satisfaction and repurchase intentions Developing Country Studies. 6(2), 96-100.

Jen, W., \& Hu, K. (2003). Application of perceived value model to identify factors affecting passengers repurchase intentions on city bus: a case of the taipei metropolitan area. Kluwer Academic Publishers, 307327.

Khan, S., Hussain, S.M., \& Yaqoob, F.(2012). Determinants of customer satisfaction in fast food industry. International Journal of Management and Strategy, 3, 56-65.

Khraim, S.H., Al-Jabaly, M.S.,\& Khraim.S.A. (2014). The effect of perceived value and customer satisfaction on perceived price fairness of airline travelers in jordan. Universal Journal of Management, 2(5), 186-196.

Kotler, P. \& Keller, K.L. (2007).Manajemen pemasaran, $\left(12^{\text {th }}\right.$ ed. Jilid 2). Jakarta: PT Indeks.

Koyong, F.T., Tumbel, L.A., \& Sepang, L.J. (2016). Pengaruh bauran promosi terhadap kepuasan konsumen pada novotel Manado golf resort \& convention center. Jurnal EMBA, 4 (2), 768-777.

Krisna, D.P.L (2010). Analisis faktorfaktor yang mempengaruhi kepuasan pelanggan produk l'oreal paris (Studi pada pelanggan L'oréal Paris di Matahari departement store Java Supermall Semarang). (Skripsi). Universitas. Diponegoro. Semarang.

Kurniawan, B., \& Kuncoro, A.E. (2014). Peranan service quality dan 
perceived value untuk meningkatkan customer satisfaction yang berdampak pada repurchase intention konsumen rumah makan makassar di jakarta jurnal Studi Manajemen \& Organisasi. 4(2), 111.

Lupiyoadi, R., \& Hamdani A. (2013). Manajemen Pemasaran Jasa. (3th ed.). Jakarta: Salemba Empat

Ma'ruf, H. (2005) .Pemasaran Ritel. Jakarta: PT. Gramedia Pustaka Utama.

Mosavi, S. A., \& Ghaedi, M. (2011). A survey on the relationships between perceived value and customer advocacy behavior. Journal International Conference on Innovation, Management and Service, 14, 249-254.

Mowen, J.C., \& Minor, M. (2002). Perilaku konsumen. (5th ed. jilid 2). Jakarta: Erlangga.

Muzahid, M.A. \& Noorjahan, P. (2009). Impact of service quality, trust, and customer satisfaction on customer loyalty. ABAC Journal, 29(1), 24-38.

Rahab., Retno, H.S., \& Tri, N.A. (2015). Peran perceived value dan kepuasan pelanggan dalam upaya membangun loyalitas pengguna kartu seluler. Media Ekonomi Dan Manajemen, 30 (1), 76 - 84.Ravald, A., \& Gronroos, C. (1996). The value concept and relationship marketing. European Journal of Marketing, 16(3), 19-30.

Roza , S. (2011). Analisis faktor-faktor yang mempengaruhi kepuasan pelanggan pengguna kartu simpati di kota Jambi. Jurnal Penelitian
Universitas Jambi:

Seri

Humaniora, 13 (1), 25-34.

Solvang, B.K. (2007). Satisfaction, loyalty, and repurchase: a study of Norwegian costumer satisfaction, dissatisfaction and complaining behavior. Journal STIESIA, 12, 83107.

Sugiyono. (2010). Metode penelitian kuantitatif, kualitatif, dan $R \& D$. Bandung: Penerbit Alfabeta.

Subagio, H., \& Saputra, R. (2012). Pengaruh perceived service quality, perceived value, satisfaction dan image terhadap customer loyalty (studi kasus garuda indonesia). Jurnal Manajemen Pemasaran, 7(1), $42-52$

Sweeney, J.C., \& Soutar, G. N. (2001). Customer perceived value: the development of a multiple item scale.Journal of Retailing, 77, 203220.

Syamsiah, N. (2009). Analisis faktorfaktor yang mempengaruhi nilai yang dirasakan pelanggan untuk menciptakan kepuasan pelanggan di RSUPdokter kariadi Semarang (studi kasus pada paviliun garuda rsup Dr.kariadi). (Tesis). Universitas Diponegoro,Semarang.

Tjiptono, F. (2008).Strategi pemasaran. (3th ed.). Yogyakarta:ANDI.

Triastuti, F. R. J., \& Tae, A. F. (2012). Analisis pengaruh kuaitas pelayanan, kualitas produk dan promosi penjualan terhadap minat membeli ulang konsumen (studi pada buket koffee+jazz Semarang)". Diponogoro Journal Of Management,1(1), 1-13. 
Triandinny, M. (2015). Kebijakan harga dan promosi kartu perdana simpati mempengaruhi kepuasan mahasiswa di universitas negeri surabaya kampus ketintang. Jurnal Pendidikan Tata Niaga (JPTN),3(1), 1-11.

Tunjungsari, K.H., \& Lunardy. D. (2016). Pengaruh persepsi nilai pada intensi pembelian produk virtual yang dimediasi oleh kepuasan.Jurnal Ilmiah Manajemen, 6(2), 261-279.

Umar, H. (2003). Metode riset bisnis. (2th ed.). Jakarta: PT. Gramedia Pustaka Utama.

Umar, H. (2008). Metode penelitian untuk skripsi dan tesis bisnis. Jakarta : PT Raja Grafindo Persada

Yougov. (16 september 2015).

Transportasi online vs ojek pangkalan 'apa kata pelanggan'. Di unduh dari (https://www.infokomputer.com/201 5/09/berita/berita-reguler/gojek-vsojek-pangkalan-apa-kata-pelanggan/ tanggal 15 Desember 2016.

Yunanto, (21 Januari 2016). Gojek dan Revolusi Transportasi Umum. di unduh dari https:/tirto.id/gojek-danrevolusi-transportasi-umum-b2 tanggal 16 Desember 2016.

Yulisetiarini, D., Subagio, A., Paramu, H., \& Irawan, B. (2017). Customer repurchase intention and satisfaction in online shopping. C Medwell Journals, 1(1),215-221. 